\title{
KONSEP PEMBIAYAAN DALAM MENUNJANG DUNIA PENDIDIKAN
}

\author{
Kadek Rai Suwena \\ Jurusan Pendidikan Ekonomi, Fakultas Ekonomi dan Bisnis \\ Universitas Pendidikan Ganesha \\ Singaraja, Indonesia \\ e-mail: kadek_suwena@yahoo.co.id
}

\begin{abstract}
Abstrak
Administrasi anggaran biaya sekolah pendidikan merupakan seluruh proses kegiatan yang direncanakan dan diusahakan secara sengaja dan bersungguh-sunggguh, serta pembinaan secara kontinyu terhadap biaya operasional sekolah/ pendidikan, sehingga kegiatan operasional pendidikan semakin efektif dan efisien, demi membantu tercapainya tujuan pendidikan yang telah ditetapkan. Secara garis besar kegiatannya meliputi pengumpulan/ penerimaan dana yang sah (dana rutin, SPP, sumbangan BP3, donasi dan usaha-usaha halal lainnya), penggunaan dana dan pertanggungjawaban dana kepada pihak-pihak terkait yang berwenang. Dalam upaya penggunaan dana dan pertanggungjawabannya diperlukan adanya strategi yang tepat. Seperti yang kita ketahui, strategi itu sendiri dipenggaruhi oleh misi organisasi atau lembaga (sekolah) dan lingkungannya. Dalam menentukan strategi diperlukan analisis masa lalu dan lingkungan ekstrem yang mencakup kekuatan (strength), kelemahan (weakness), peluang (opportunities) dan ancaman (threats) berkaitan dengan implementasi dari pembiayaan yang akan dilaksanakan. Implementasi pembiayaan dalam dunia pendidikan dapat dimulai dari lingkungan keluarga, sekolah dan yang berujung pada lingkungan masyarakat (pemerintah). Maka sosialisasi gencar untuk meyakinkan pemerintah agar mengalokasikan anggaran sektor pendidikan dalam jumlah yang cukup harus terus dilakukan. Tanpa usaha seperti itu, nasib sektor pendidikan saat otonomi daerah dilaksanakan hanya asal terlaksana saja.
\end{abstract}

Kata Kunci: pembiayaan, pendidikan

\begin{abstract}
Administration of the school budget to the entire process of education is planned and cultivated intentionally and mean sunggguh, as well as the continuous development of the operational costs of the school / education, so that education operations more effectively and efficiently, in order to help achieve the educational goals that have been set. Broadly speaking activities include the collection / receipt of funds authorized (regular funds, tuition, donations BP3, donations and other lawful efforts), the use of funds and accountability of funds to related parties authorized. In an effort to use the funds and accountability necessary to have the right strategy. As we know, the strategy itself dipenggaruhi by the mission of the organization or institution (school) and the environment. In determining the required analysis of past strategies and extreme environments that include strength (strength), weakness (weakness), opportunities (opportunities) and threats (threats) related to the implementation of the financing to be implemented. Implementation in education financing can be started from the family, school and community environments that led to the (government). So intense socialization to convince the government to allocate the education sector budget in sufficient quantities should be done. Without such efforts, the fate of the education sector is currently only implemented decentralization origin accomplished alone.
\end{abstract}

Keywords: finance, education

Kadek Rai Suwena | 1 


\section{PENDAHULUAN}

Konsep biaya itu mulai berlaku dalam produksi barang atau jasa, dimana biaya erat kaitannya dengan transaksi ekonomi yang dilakukan oleh produsen, penjual, pembeli, atau konsumen dalam bentuk uang atau moneter. Beberapa ahli ekonomi membedakan biaya yang sebenarnya dengan pengeluaran. "Terdapat perbedaan antara biaya yang sebenarnya yang berhubungan dengan usaha atau pengorbanan yang diperlukan untuk memproduksi barang dan jasa dengan biaya yang terdiri dari pengeluaran untuk membayar para pemilik faktor produksi" (Marshall dan Hallak, 1985 dalam Fattah, 2004). Biaya dalam pengertian uang bagi seorang konsumen dianggap mewakili atau semua dengan biaya yang sebenarnya yang dikeluarkan oleh seorang produsen. Namun demikian, karena ada rantai transaksi ekonomi yang dimulai oleh pemilik atau produsen dan berakhir di konsumen terakhir, maka bagian transaksi di bagian atas sama atau lebih tinggi dari pada grosir, karena ada tambahan ongkos pembelian. Demikian pula, harga grosir lebih tinggi daripada harga yang ditentukan oleh produsen.

Secara teoritis, konsep biaya di bidang lain mempunyai kesamaan dengan bidang pendidikan, dimana lembaga pendidikan dipandang sebagai produsen jasa pendidikan yang menghasilkan keahlian, keterampilan, ilmu pengetahuan, karakter, dan nilai-nilai yang dimiliki oleh seorang lulusan. Kegiatan pendidikan sebenarnya dapat dipandang sebagai pelayanan (services) terhadap siswa atau peserta didik selama belajar. Pendidikan sebagai proses produksi yang menghasilkan lulusan yang berhasil dapat ditentukan oleh jumlah pendaftar dan komponen-komponen input dalam suatu sistem pendidikan. Namun demikian, pada skala ekonomi mikro dan tingkatan keluarga atau suatu lembaga pendidikan, tidak terdapat hubungan yang fungsional antara biaya bagi produsen (lembaga) dengan biaya bagi konsumen (keluarga). Persoalannya, lembaga pendidikan pada umumnya tidak langsung menanggung seluruh biaya, karena gaji guru dan sarana pendidikan dominan bersumber dari pemerintah. Sedangkan uang pemerintah sebagian besar dari masyarakat melalui pembebasan wajib pajak. Pajak yang dibayar oleh masyarakat dipandang sebagai biaya tidak langsung. Oleh karena itu, pendidikan dapat dipandang sebagai aktivitas yang bersifat pelayanan umum.

Transaktor ekonomi yang berhubungan dengan pendidikan dapat dibedakan menjadi dua golongan, yaitu (1) golongan produsen dan (2) golongan konsumen. Para produsen pendidikan terdiri dari pendidik, pengelola pendidikan, badan/lembaga anak di rumah. Sedangkan konsumen (costumers) pendidikan dapat terdiri dari keluarga atau orang tua siswa, siswa itu sendiri, lembaga-lembaga pemerintahan atau swasta, dan masyarakat secara umum. Biaya bagi keluarga ialah uang sekolah dan pajak yang dibayar kepada pemerintah yang sebagian oleh pemerintah digunakan untuk membiayai pendidikan. Di samping itu, biaya kesempatan (opportunity cost) dan pendapatan yang hilang (earning forgone) selama mengikuti pendidikan, yang masih perlu dipertanyakan apakah biaya tersebut harus diperhitungkan.

Latar belakang perlunya landasan ekonomi dalam pendidikan (1) pendidikan yang kurang mengajarkan cara pandang produktif; (2) lembaga pendidikan yang kurang membangun interpreneurship (kemampuan menjual dan membeli); (3) hidup melebihi dari kemampuan; (4) belum mengembangkan rasa percaya yang optimal; (5) kurang menawarkan program studi yang dipasarkan. Kalau ya strategi pemasaran yang kurang strategis. (Sedanayasa, 2006).

Dampaknya (1) angka pengangguran makin membengkak; (2) pengangguran terselubung makin bertambah; dan (3) pegangguran akibat pemutusan hubungan kerja (PHK). Arah 
pendidikan nasional ada dua Pertama, prinsip kemandirian dalam pendidikan dan prinsip pemerataan menuntut warga Negara secara individual maupun kolektif untuk memiliki kemampuan bersaing dan sekaligus kemampuan bekerjasama. Kedua, tujuan pendidikan nasional, menjadikan manusia trampill dan mandiri. Dalam hubungannya dengan biaya dan manfaat, pendidikan dapat dipandang sebagai salah satu bentuk investasi.

\section{HASIL DAN PEMBAHASAN Konsep Dasar Pembiayaan Dalam Pendidikan}

Administrasi anggaran biaya sekolah pendidikan merupakan seluruh proses kegiatan yang direncanakan dan diusahakan secara sengaja dan bersungguh-sunggguh, serta pembinaan secara kontinu terhadap biaya operasional sekolah/ pendidikan, sehingga kegiatan operasional pendidikan semakin efektif dan efisien, demi membantu tercapainya tujuan pendidikan yang telah ditetapkan. Secara garis besar kegiatannya meliputi pengumpulan/ penerimaan dana yang sah (dana rutin, SPP, sumbangan BP3, donasi dan usaha-usaha halal lainnya), penggunaan dana dan pertanggungjawaban dana kepada pihakpihak terkait yang berwenang.

Dana yang datang/ masuk itu disebut dana masukan (input) yang kemudian setelah dilakukan perencanaan anggaran (budgeting) lalu digunakan dalam pelaksanaan proses/ operasional pendidikan (throughput) dan akhirnya dipertanggungjawabkan sesuai ketentuan yang berlaku bersama hasil usaha (output) yang dihasilkan.

Mejelang atau pada awal tahun ajaran, pimpinan sekolah membuat perencanaan anggaran pendapatan dan belanja sekolah (RAPBS) untuk diajukan kepada Kakanwil Depdikbud Provinsi (atau Kakan Depdikbud Kabupaten atau Kodya) untuk mendapatkan persetujuannya/ saran perbaikannya, kemudian diajukan kepada Badan Pembantu Pelaksana Pendidikan (BP3) untuk persetujuan tentang sumbangan pedidikannya di samping SPP yang sesuai dengan persetujuan/ kategori SPP oleh Gubernur Kepala Daerah Tingkat I, sehingga akhirnya jadilah anggaran Pendapatan dan Belanja Sekolah (APBS) yang sah untuk dapat dilaksanakan atau dioperasionalisasikan. Dalam kegiatan ini agar diperhatikan sebuah semboyan yang berbunyi: "janganlah pasak lebih besar dari tiangnya.

Biaya operasional pendidikan atau sekolah terdiri dari biaya untuk kegiatan belajar-mengajar, gaji dan honorarium guru dan pegawai TU, alat tulis kantor (ATK), pemeliharaan dan rehabilitasi serta lain-lain kegiatan seperti acaraacara awal dan tutup tahun ajaran, kemah, karyawisata dan lain-lain.

Dalam uraian sebelumnya telah dijelaskan mengenai administrasi keuangan sebagai sebuah kebutuhan dalam menunjang terlaksananya pendidikan. Namun tidak selamanya kebutuhan akan dapat terpenuhi, hal ini disebabkan karena sifat manusia yang tidak pernah puas terhadap apa yang telah mereka raih dengan kebutuhan yang tak terbatas sedangkan alat pemuas kebutuhan yang terbatas dan mempunyai kegunaan alternatif, dalam konsep ekonomi sering disebut dengan kelangkaan.

Terbatas artinya jumlah barang dan jasa yang diperlukan manusia tidak selamanya ada dan tidak mudah diperoleh. Misalnya: kebutuhan manusia akan pendidikan, tidak semua dan selamanya manusia tersebut dapat menikmati pendidikan. Hal ini tergantung dari kemampuan manusia tersebut dalam memenuhi kebutuhan akan pendidikan. Ada manusia yang mampu untuk memenuhi kebutuhan akan pendidikan namun manusia yang bersangkutan tidak ada kemauan untuk memenuhinya, sedangkan fenomena di lain pihak ada manusia yang ingin memenuhi kebutuhan akan pendidikan namun tidak mampu untuk memenuhinya karena adanya keterbatasan kemampuan untuk 
memenuhi kebutuhan akan pendidikan tersebut.

Mempunyai kegunaan alternatif artinya bahwa barang dan jasa dapat digunakan dalam berbagai kemungkinan perolehan manfaat yang berbeda-beda. Ini tergantung kepada keputusan manusia, bagaimana barang dan jasa itu akan digunakan. Misalnya: komputer, pengunaan komputer dapat digunakan untuk berbagai alternatif tujuan. Misalnya: dapat digunakan untuk menyimpan datadata, mengakses informasi melalui internet, dapat digunakan mengetik, dapat digunakan untuk memutar film CD ataupun DVD. Namun tidak semua manusia dapat memenuhi kebutuhan akan computer padahal kebutuhan akan computer saat ini sangat penting, hal ini kembali lagi disebabkan karena keterbatasan kemampuan manusia.

Upaya pemenuhan kebutuhan ini pada dasarnya tak pernah berakhir, karena sifat kebutuhan manusia baik jumlah dan jenisnya tak terbatas. Juga selama hayat dikandung badan, manusia selalu mempunyai kebutuhan untuk mempertahankan hidupnya. Sementara itu alat pemuas kebutuhan yang terdiri dari barang dan jasa itu terbatas bahkan seringkali jarang dan sukar ditemukan. Sekali alat pemuas kebutuhan itu diperoleh maka manusia dihadapkan pada pilihan untuk penggunaan alat pemuas kebutuhan itu dalam berbagai kemungkinan atau alternatif penggunaan. Artinya barang dan jasa yang telah diperoleh dapat digunakan bukan saja untuk satu kebutuhan tetapi mungkin juga untuk pemenuhan kebutuhan yang lain yang dirasakan lebih penting. Nah, jadi manusia tidak pernah berhenti untuk berpikir dan belajar untuk memenuhi kebutuhannya selama ia masih bernapas.

\section{Strategi Dalam Mempersiapkan Pembiayaan Pendidikan}

Strategi secara sederhana dapat didefinisikan sebagai keputusan atas tindakan yang berusaha untuk mencapai sasaran organisasi. Strategi itu sendiri dipenggaruhi oleh misi organisasi atau lembaga (sekolah) dan lingkungannya. Dalam menentukan strategi diperlukan analisis masa lalu dan lingkungan ekstren yang mencakup kekuatan (strength), kelemahan (weakness), peluang (opportunities) dan ancaman (threats)

1) Keluarga

Memberikan pemahaman yang baik dan benar; (b) Mengajarkan pola hidup hemat pangkal kaya, melalui menabung; (c) Memelihara dan bertanggung jawab terhadap fasilitas yang ada dirumah khususnya terkait dengan sarana prasarana; (d) Mengajarkan pemanfaatan barang bekas menjadi bernilai ekonomis; (e) Memberikan contoh-contoh cara belajar yang benar, efektif dan efisiensi; dan (f) Mengajarkan cara pandang yang efektif.

2) Sekolah

Usaha-usaha misalnya: (a) Mengadakan seni pentas keliling atau dipentaskan di masyarakat; (b) Menjual hasil karya nyata anak-anak; (c) Membuat bazaar; (d) Mendirikan koperasi; (e) Mendirikan toko keperluan personalia pendidikan dan anak-anak; (f) Mencari donator tetap; (g) Mengumpulkan sumbangan; dan (h) Mengaktifkan komite sekolah khusus meningkatkan dana pendidikan.

3) Masyarakat

(a) Memberikan pemahaman yang baik dana benar; (b) Mengajarkan pola hidup hemat dan bersahaja; (c) Memelihara dan bertanggung jawab; (d) Mengajarkan memanfaatkan barang bekas menjadi bernilai ekonomis; (e) Memberikan contohcontoh cara belajar yang benar efektif, dan efisiensi; (f) Pembelajaran life skill; (g) Membangun etos kerja dan semangat berwirausaha; Membangkitkan semangat belajar dan kerja; dan (i) Mengaktifkan usia produktif melalui kelompok belajar usaha. 
Implementasi Konsep Pembiayaan Dalam Menunjang Pendidikan

1) Dalam Lingkungan Keluarga

Biaya Satuan Pendidikan (BSP) di Tingkat Orangtua.

Biaya satuan pendidikan (BSP) ditingkat orangtua siswa adalah nilai uang dari segala sumber daya yang disediakan oleh orangtua/siswa untuk memperoleh pendidikan di sekolah

1) Biaya satuan pendidikan (BSP) ditingkat orangtua meliputi:

biaya buku dan alat tulis sekolah (ATS). Biaya yang dikeluarkan untuk pembelian semua buku dan alat tulis sekolah yang diperlukan oleh siswa untuk belajar.

a) Buku dan ATS tersebut meliputi buku pelajaran, lembar kerja siswa (LKS), buku tulis, buku gambar, peta pulpen, pensil warna, rautan, penggaris.

Berdasarkan sifat penggunaannya, BSP tingkat sekolah/madrasah dapat diklasifikasikan ke dalam BSP langsung dan BSP tidak langsung.

b) Biaya pakaian dan perlengkapan sekolah. Biaya yang dikeluarkan untuk pembelian pakaian dan perlengkapan sekolah siswa. Pakaian dan perlengkapan sekolah ini mencakup seragam nasional, seragam sekolah, seragam olah raga, seragam pramuka, jaket almamater, atribut (badge) sekolah, baju lab/praktikum, tas, sepatu, alat musik, alat olah raga, meja dan kursi belajar, lampu belajar, komputer, kalkulator, dan sebagainya.

c) biaya akomodasi, biaya yang dikeluarkan untuk pengadaan tempat tinggal siswa dalam mengikuti proses pembelajaran. Akomodasi dapat berupa rumah orang tua, asrama, rumah kost, rumah kontrakan, dan lain sebagainya.

d) biaya transportasi, biaya yang dikeluarkan untuk keperluan transportasi siswa dalam mengikuti proses pembelajaan. Transportasi siswa dapat berupa kendaraan sendiri seperti sepeda, sepeda motor, mobil, perahu, dan lain lain atau kendaraan umum seperti bis, kereta api, ojek sepeda, ojek sepeda motor, andong, becak, perahu penyebrangan dan lain-lain

e) biaya konsumsi, biaya yang dikeluarkan untuk keperluan makan dan minum siswa dalam mengikuti proses pembelajaran. Konsumsi di sini mencakup makanan pokok (pagi, siang, dan malam) dan makanan tambahan.

f) biaya kesehatan, biaya yang dikeluarkan untuk keperluan kesehatan siswa. Biaya kesehatan ini mencakup biaya untuk rumah sakit, dokter, para medis, asuransi kesehatan, obat-obatan, vitamin, dan perlengkapan mandi.

g) biaya karyawisata, biaya yang dikeluarkan untuk keperluan karya wisata meliputi kunjungan ke tempat-tempat bersejarah, rekreasi, dan lain-lain.

h) uang saku, uang yang diberikan kepada siswa untuk membeli makanan, minuman, dan/atau tabungan.

i) biaya kursus, biaya yang dikeluarkan untuk mengikuti kegiatan kursus yang dapat meningkatkan prestasi belajar siswa. Kursus ini meliputi kursus mata pelajaran, kursus musik, kursus melukis, kurusu tari, kursus oleh raga, pesantren kilat, dan lain-lain.

j) uang iuran sekolah, Seluruh jenis iuran yang dibayarkan orangtua ke sekolah meliputi: iuran komite sekolah (iuran BP3/POMG); iuran SPP; sumbangan awal tahun siswa baru/iuran gedung; daftar ulang siswa lama; uang evaluasi hasil belajar; uang UAN/UAS; uang paraktikum; uang komputer; uang kursus/les di sekolah; iuran 
ekstrakulikuler (bela diri, pramuka, berenang, dan lain-lain); iuran OSIS; iuran koperasi; iuran pendidikan Sistem Ganda; dan sumbangan lainnya. luran sekolah digunakan oleh sekolah untuk membiayai kebutuhan sekolah. Oleh karena itu, iuran sekolah ini dapat sama dengan komponenkomponen biaya lain yang dikeluarkan sekolah.

k) Forgone earning, potensi penghasilan yang tidak jadi diterima oleh siswa karena siswa harus mengikuti proses pembelajaran di sekolah, dan karenanya tidak bekerja dan memperoleh penghasilan. Mestinya forgone earning berlaku untuk siswa SLTA, karena Undang-undang Sistem Pendidikan Nasional menetapkan wajib belajar sampai jenjang SLTP. Akan tetapi kenyataannya terdapat anak usia SD dan SLTP yang juga bekerja mencari nafkah

2) Dalam Lingkungan Sekolah Biaya Satuan Pendidikan (BSP) di Tingkat Sekolah

Nilai rupiah semua sumber daya yang digunakan oleh sekolah/madrasah untuk menyelenggarakan pendidikan per tahun per siswa. Berdasarkan jenis penggunaannya, BSP tingkat sekolah/madraah tersebut terdiri dari BSP operasional/lancar dan BSP investasi/modal.

a) BSP Operasional

Biaya yang dikeluarkan untuk menyediakan sumber daya yang habis dipakai atau dikeluarkan dalam waktu satu tahun atau kurang per siswa per tahun. BSP operasional terdiri dari BSP operasional personel dan BSP operasional bukan personel. Terdiri dari BSP operasional personel dan BSP operasional bukan personel.
(1) BSP Operasional Personel adalah biaya satuan yang dikeluarkan untuk kesejahteraan dan pengembangan personel atau SDM sekolah per tahun per siswa. SDM di sekolah terdiri dari kepala sekolah, wakil kepala sekolah, guru PNS, guru tetap yayasan (khusus untuk sekolah swasta), guru honorer, guru diperbantukan (Dpk), pegawai tata usaha, tenaga laboratorium/bengkel, pegawai perpustakaan, pesuruh sekolah, dan satpam. Pengeluaran untuk kesejahteraan personel sekolah mencakup pengeluaran-pengeluaran untuk gaji/honor, tunjangan jabatan, kesra, transport, seragam, kelebihan jam mengajar/kerja, tunjangan hari raya, dana sosial, konsumsi, dan asuransi/kesehatan.

Pengeluaran untuk pengembangan personel meliputi pengeluaranpengeluaran untuk lokakarya, seminar, magang, pelatihan, penataran, dan pendidikan personel sekolah yang tujuannya adalah untuk meningkatkan kemampuan personel sekolah dalam menjalankan tugasnya, baik tugas mengajar (untuk guru), tugas

administrasi/manajemen

(untuk kepala sekolah dan pegawaii administrasi), dan tugas-tugas sekolah lainnya.

(2) BSP Operasional Bukan Personel adalah biaya satuan yang dikeluarkan untuk pengadaan segala bahan dan alat yang dibutuhkan untuk proses belajar mengajar atau mengadakan berbagai kegiatan yang menunjang 
proses belajar mengajar dalam satu tahun per siswa. Termasuk dalam biaya satuan operasional bukan personel adalah alat tulis sekolah; daya dan jasa (listrik, telepon, gas, dII); pemeliharaan dan perbaikan ringan untuk gedung, peralatan, perabot, dan mebeler; pembinaan siswa; pendidikan sistem ganda (khusus untuk SMK); pembinaan, pemantauan, pengawasan, dan pelaporan; peralatan olahraga; bahanbahan praktikum; rapat pengurus sekolah; kegiatan komite sekolah; dan lain-lain.

b) BSP Investasi

Biaya yang dikeluarkan untuk menyediakan sumber daya yang tidak habis dipakai atau dikeluarkan dalam waktu lebih dari satu tahun, yang kemudian dibagi menjadi per tahun dan per siswa. Termasuk dalam biaya satuan investasi adalah biaya-biaya untuk membangun, menyediakan, dan/atau membeli tanah; bangunan; peralatan dan perlengkapan; perabot dan mebeler; buku-buku; jaringan listrik, telepon, air, dan gas; taman; fasilitas olahraga; dan lainlain.

Berdasarkan sifat penggunaannya, BSP tingkat sekolah dapat diklasifikasikan ke dalam BSP langsung dan BSP tidak langsung.

(1) BSP Langsung adalah biaya satuan yang dikeluarkan untuk kebutuhan input yang langsung terkait dengan proses belajar. Termasuk dalam biaya satuan pendidikan langsung di tingkat sekolah ini adalah gaji guru dan tenaga kependidikan lainnya; pembelian bahan, peralatan dan perlengkapan belajar; pembangunan gedung untuk belajar dan guru; dll.

(2) BSP tidak langsung adalah biaya yang dikeluarkan untuk kegiatan-kegiatan yang tidak berkaitan langsung dengan proses belajar mengajar tetapi menunjang proses belajar mengajar tersebut, seperti gaji kepala sekolah dan pegawai administrasi; pembelian bahan, peralatan dan perlengkapan untuk kepala sekolah dan pegawai administrasi; pembangunan gedung untuk kepala sekolah dan pegawai administrasi; dll.

3) Dalam Masyarakat (Pemerintah)

\begin{tabular}{lr}
\multicolumn{2}{c}{ Pendanaan pendidikan } \\
dalam masyarakat & telah \\
ditetapkan dengan & adanya \\
Undang-Undang & Sistem \\
Pendidikan Nasional & (UU
\end{tabular}
Sisdiknas) Tahun 2003. Dimana dalam Undang-Undang tersebut telah diatur sebagai berikut:

(1) Tanggung jawab pendanaan (Pasal 46 UU Sisdiknas)

Pendanaan pendidikan menjadi tanggung jawab bersama antara pemerintah, pemerintah daerah dan masyarakat sebagaimana diatur dalam pasal 31 ayat (4) Undang-Undang Dasar Negara Republik Indonesia 1945.

(2) Sumber pendanaan pendidikan (Pasal 47 UU Sisdiknas)

Sumber pendanaan pendidikan ditentukan berdasarkan prinsip keadilan, kecukupan dan berkelanjutan. Pemerintah daerah dan masyarakat mengarahkan sumber daya yang ada sesuai dengan peraturan perundangundangan yang berlaku. 
(3) Pengelolaan dana pendidikan (Pasal 48 UU Sisdiknas) Pengelolaan dana pendidikan berdasarkan pada prinsip keadilan, efisiensi, transparansi dan akuntabilitas publik.

(4) Pengalokasian dana pendidikan (Pasal 49 UU Sisdiknas)

Dana pendidikan selain gaji pendidik dan biaya pendidikan kedinasan dialokasikan minimal 20\% dari Anggaran Pendapatan dan Belanja Negara (APBN) pada sektor pendidikan dan minimal $20 \%$ dari Anggaran Pendapatan dan Belanja Daerah (APBD). Gaji guru dan dosen yang diagkat oleh pemerintah dialokasikan dalam Anggaran Pendapatan dan Belanja Negara (APBN).

Dana pendidikan dari pemerintah dan pemerintah daerah untuk satuan pendidikan diberikan dalam bentuk hibah sesuai dengan peraturan perundangundangan yang berlaku.

\section{SIMPULAN}

Hampir dapat dipastikan bahwa proses pendidikan tidak dapat berjalan tanpa dukungan biaya yang memadai. Implikasi diberlakukannya kebijakan desentralisasi pendidikan, para pengambil keputusan seringkali mengalami kesulitan untuk mendapatkan referensi tentang komponen-komponen pembiayaan pendidikan. Kebutuhan tersebut dirasakan semakin mendesak sejak dimulainya pelaksanaan otonomi daerah yang juga meliputi bidang pendidikan. Apalagi masalah pembiayaan ini sangat menentukan kesuksesan program Manajemen Berbasis Sekolah (MBS).

$\begin{array}{lcc}\text { Cukup banyak studi yang } & \text { sti } \\ \text { dilakukan } & \text { tentang } & \text { pembiayaan } \\ \text { pendidikan di Indonesia. Fokusnya lebih }\end{array}$

pada anggaran pemerintah, dengan mengabaikan peranan dana masyarakat, khususnya keluarga siswa. Sementara itu, pemerintah senantiasa mengundang masyarakat/keluarga untuk berperan serta lebih besar dalam pembiayaan pendidikan, tanpa pengetahuan yang cukup tentang berapa besar selama ini mereka telah memberikan kontribusi dimaksud. Dapat dikatakan bahwa belum banyak studi tentang pembiayaan pendidikan yang berbasis "dana masyarakat dan keluarga" di tingkat sekolah, sehingga kontribusi sumber dana ini cenderung diabaikan. Masalah pendidikan yang tidak pernah dianggap isu kuat telah mempengaruhi banyak hal, di antaranya menyangkut anggaran. Selama pendidikan tidak menjadi isu kuat, seperti halnya bidang ekonomi dan politik, anggaran pendidikan tak pernah akan diberi alokasi memadai.

Padahal dunia pendidikan sedang ditantang untuk, menjawab tiga hal: kemampuan memenuhi kebutuhan, kemampuan mengembangkan hidup yang bermakna, dan kemampuan memuliakan hidup. Disisi lain, pendidikan juga dihadapkan pada globalisasi, yang antara lain ditandai industrialisasi pendidikan. Tapi sayang pemerintah kurang serius menghadapi tantangan itu. Indikasinya tampak dari kecilnya alokasi dana yang dianggarkan untuk dunia pendidikan

Permasalahan akan semakin ruwet bila dikaitkan dengan pelaksanaan otonomi daerah dalam sektor pendidikan. Maka sosialisasi gencar untuk meyakinkan pemerintah agar mengalokasikan anggaran sektor pendidikan dalam jumlah yang cukup harus terus dilakukan. Tanpa usaha seperti itu, nasib sektor pendidikan saat otonomi daerah dilaksanakan hanya asal terlaksana saja.

Padahal pendidikan mempunyai peranan yang penting dalam peningkatan kualitas sumber daya manusia. Pendidikan mempengaruhi secara penuh pertumbuhan ekonomi suatu bangsa. Negara yang memiliki penduduk dengan 
tingkat pendidikan yang tinggi akan mempunyai tingkat pertumbuhan ekonomi yang pesat. Oleh karena itu, masalah pembiayaan pendidikan menjadi sangat strategis untuk dikaji bagaimana hubungannya dengan permasalahan pendidikan.

\section{DAFTAR PUSTAKA}

Fatah, Nanang, Dr. 2004. Ekonomi Dan Pembiayaan Pendidikan. Bandung: PT. Remaja Rosdakarya.

Ghozali, Abbas dkk. 2004. Studi Pembiayaan Pendidikan Dasar dan Menengah. Jakarta.
Badan Penelitian Dan Pengembangan Pendidikan Nasional Jakarta Maret 2004.

Sedanayasa, Gede. 2006. Catatan Perkuliahan Landasan

Pendidikan. Untuk Kalangan sendiri Program Pascasarjana Manajemen Pendidikan Universitas Pendidikan Ganesha Singaraja-Bali.

Supriadi, Dedi. 2004. Satuan Biaya Pendidikan Dasar dan Menengah. Bandung. PT. Remaja Rosdakarya.

Undang-Undang Sistem Pendidikan Nasional (UU Sisdiknas) Tahun 2003 